\title{
Ameliorative Effect of Teucrium polium Extract on $\gamma$-radiation Toxicity in Brain of Albino Rats
}

\author{
Mostafa Saif-Elnasr ${ }^{(1) \#}$, Salma M. Abdel Fattah ${ }^{(2)}$, Tarik A. Mohamed ${ }^{(3)}$ \\ ${ }^{(1)}$ Health Radiation Research Department, National Center for Radiation Research \\ and Technology (NCRRT), Egyptian Atomic Energy Authority (AEA), P.O. Box 29, \\ Nasr City, Cairo, Egypt; (2)Drug Radiation Research Department, National Center \\ for Radiation Research and Technology (NCRRT), Egyptian Atomic Energy Authority \\ (AEA), P.O. Box 29, Nasr City, Cairo, Egypt; (3)Phytochemistry Department, National \\ Research Center, Giza 12622, Egypt.
}

$\mathbf{T}$

HE IMPAIRMENT to the healthy brain tissue is a crucial factor limiting the application of radiation therapy in patients with nervous system neoplasms. Teucrium polium (TP) L. (family Lamiaceae), a wild-growing flowering plant, has beneficial curative properties. The flavonoids of TP have many valuable biological activities. This study aims atinvestigating the ameliorative effect of TP extract on $\gamma$-radiation toxicity in brain of albino rats.

Thirty adult male albino rats were used. Ionizing irradiation was performed by whole body exposure of rats to $8 \mathrm{~Gy}$. TP was administered by intragastric tube in a dose of $200 \mathrm{mg} /$ kg body weight. Animals were divided into five groups: Group I (control), Group II (TP), Group III ( $\gamma$-irradiated), Group IV (TP $+\gamma$-irradiated) and Group V (TP $+\gamma$-irradiated $+\mathrm{TP})$. The action of TP extract was investigated after one week post irradiation by measuring serum liver and renal functions, and oxidative stress parameters in brain tissue. Moreover, serum S100B and brain-derived neurotrophic factor (BDNF) in brain tissue were measured, in addition to histopathological examination.

TP at a dose of $200 \mathrm{mg} / \mathrm{kg}$ body weight did not have hepatotoxic or nephrotoxic effects. TP extract significantly ameliorated $\gamma$-radiation-induced brain damage by improving radiationinduced oxidative stress. The role of the extract was confirmed by improvement of the levels of $\mathrm{S} 100 \mathrm{~B}$ in the serum and BDNF in the brain as well as amelioration of histopathological changes induced by radiation. The administration of TP before and after irradiation was more effective than administration only before irradiation. These results revealed that the administration of TP extract might ameliorate $\gamma$-radiation-induced brain injury by the attenuation of oxidative stress, the regulation of BDNF and the suppression of S100B.

Keywords: Teucrium polium, $\gamma$-radiation, brain, oxidative stress, S100B, Brain-derived neurotrophic factor.

\section{Introduction}

Exposure of the central nervous system (CNS) to ionizing radiation occur during a number of clinical situations; radiotherapy remains a major treatment modality for primary and metastatic neoplasms located in the CNS (Caruso et al., 2013). Exposure of the spinal cord and the brain is frequently unavoidable in the radiotherapeutic management of tumors located nearby the CNS such as cancers of head and neck. In addition, there is a growing radiation application in management of other brain disorders as epilepsy (Régis et al., 1999). Radiation-induced brain injury (RIBI) is still a prominent and serious side effect in spite of current advances in radiation delivery and planning procedures, and the neuroprotective therapies for RIBI are insufficient. Therefore, preclinical studies are crucial to find an active radio-neuroprotector and unravel its possible mechanisms. Oxidative stress as well plays a key role in radiation-induced cell damage, chiefly through generation of reactive oxygen species (ROS) (Mao et al., 2012).

\#Corresponding author email: mostafa_saif_elnasr@yahoo.com

Tel: +201062804651

DOI: $10.21608 /$ ejrsa.2019.9867.1065

(C)2019 National Information and Documentation Center (NIDOC) 
Oxidative stress happens when the balance between ROS and antioxidants is disturbed. A high level of polyunsaturated fatty acids contained in the brain making it more liable to oxidative damage which is an important mechanism of RIBI. In some preceding studies, ionizing radiation induced significant oxidative stress levels in neuron cells, characterized by the increase of ROS and malondialdehyde (MDA) in addition to the reduction of antioxidants including reduced glutathione, catalase and superoxide dismutase (SOD) (Rola et al., 2007; Huang et al., 2012 and Xin et al., 2012). ROS scavengers were illustrated to be effective in ameliorating radiationinduced neuronal injury (Xin et al., 2012 and Lu et al., 2015). In previous animal studies, ionizing radiation also appeared to provoke hippocampal neuronal apoptosis correlated to the learning and memory shortfalls (Huo et al., 2012; Xin et al., 2012; Hassan et al., 2013; Zhang et al., 2014 and Dong et al., 2015).

Brain-derived neurotrophic factor (BDNF) is a neurotropin which facilitates neurogenesis, neuroreg eneration, neuroprotection, synaptic plasticity, cell survival, as well as formation, retention, and recall or memory in hippocampus and frontal cortex (Bekinschtein et al., 2008).

$\mathrm{S} 100 \mathrm{~B}$ has been involved in the cell cycle progression regulation and differentiation throughout microtubule and intermediate filament assembly, and its expression is predominantly occurred in the astrocytes cytoplasm (Donato, 2001). The protein was firstly defined by Moore (1965) and after that, the variationof S100B gene has been associated with various neurological illnesses including Alzheimer's, amyotrophic lateral sclerosis and epilepsy (Otto et al., 1998; Chaves et al., 2010 and Calik et al., 2013). More importantly, S100B has emerged as a marker of the neurological damage acute phase. Following acute brain injury, astrocytes release the protein and if the blood brain barrier is compromised, it can be detected in serum. S100B, moreover, acted as a prognostic marker in outcome prediction after traumatic brain injury (TBI) and large volume cerebral infarction (Rainey et al., 2009; Egea-Guerrero et al., 2013 and Thelin et al., 2013). Additionally, an elevated serumlevel of S100B has been illustrated in ischemic stroke and is concomitant with worse outcome after a stroke (Weglewski et al., 2005 and KacaOrynska et al., 2010).
The medical use of plants dates back to ancient times. Teucrium polium (TP) L. (Lamiaceae) has been used for over two hundred years in traditional medicine owing to its diuretic, tonic, diaphoretic, antispasmodic, antipyretic and cholagogic properties (Galati et al., 2000). Furthermore, the plant owns hypoglycemic, hypolipidemic, insulinotropic, antinociceptive, antioxidant, and anti-inflammatory properties (Gharaibeh et al., 1988; Tariq et al., 1989; Rasekh et al., 2001; Abdollahi et al., 2003; Couladis et al., 2003; Esmaeili \& Yazdanparast, 2004 and Mousavi et al., 2012). TP also affects the cardiovascular system (Niazmand et al., 2011), diminishes body weight (Suleiman et al., 1988), and protects against hepatotoxicity induced by acetaminophen (Kalantari et al., 2013). It has been demonstrated that TP extract possesses antiamnesic properties in a mouse model of amnesia induced by scopolamine (Orhan \& Aslan, 2009). Hence, TP may be a herbal alternative for memory enhancement (Hasanein \& Shahidi, 2012).

In light of these beneficial effects, the aim of this study is to investigate the ameliorative effect of TP extract on $\gamma$-radiation toxicity in brain of albino rats.

\section{Materials and Methods}

\section{Preparation of plant extract}

TP plant species were collected in June 2014 from South Sinai, Egypt and aerial parts were air-dried. Plants were identified and voucher specimens were deposited in the Herbarium of Saint Katherine Protectorate, Egypt. The collection was carried out under the permission of Saint Katherine Protectorate for scientific purposes and official permission was granted from the National Research Center, Egypt. The aerial parts $(100 \mathrm{~g})$ of TP were powdered and extracted with $\mathrm{CH}_{2} \mathrm{Cl}_{2}-\mathrm{MeOH}(1: 1)$ at room temperature. The filtrate solvents extract was concentrated in vacuum using rotary evaporator to obtain a crude extract.

\section{High-performance liquid chromatography (HPLC) HPLC equipment}

HPLC analysis was performed using an Agilent 1260 series. The separation was carried out using C18 column ( $4.6 \mathrm{~mm}$ x $250 \mathrm{~mm}$ i.d., $5 \mu \mathrm{m})$.

\section{Chemicals}

The standards chemicals such as gallic acid, 
chlorogenic acid, catechin, caffeine, rutin, caffeic acid, syringic acid, pyrocatechol, coumaric acid, vanillin, ferulic acid, naringenin, propyl gallate, 4,7-dihydroxy isoflavone, quercetin, and cinnamic acid were purchased from Sigma Chemical Co. and HPLC-grade solvents such as tri-fluoro-acetic acid, acetonitrile, and water were purchased from Merck (Germany).

\section{Chromatographic analysis of phenolic compounds}

The mobile phase consisted of water (A) and $0.02 \%$ tri-fluoro-acetic acid in acetonitrile (B) at a flow rate $1 \mathrm{ml} / \mathrm{min}$. The mobile phase was programmed consecutively in a linear gradient as follows: $0 \mathrm{~min}(80 \% \mathrm{~A}) ; 0-5 \mathrm{~min}(80 \% \mathrm{~A}) ; 5-8 \mathrm{~min}$ $(40 \% \mathrm{~A}) ; 8-12 \min (50 \% \mathrm{~A}) ; 12-14 \min (80 \% \mathrm{~A})$ and $14-16 \mathrm{~min}(80 \% \mathrm{~A})$. The injection volume was $10 \mu \mathrm{l}$ for each of the sample solutions. The temperatureof column was maintained at $35^{\circ} \mathrm{C}$. HPLC chromatograms were detected using a photo diode array UV detector at wavelength $(280 \mathrm{~nm})$ according to absorption maxima of analyzed compounds. Each compound was identified by its retention time and by spiking with standards under the same conditions. The quantification of the sample was done by the measurement of the integrated peak area and the content was calculated using the calibration curve by plotting peak area against concentration of the respective standard sample. The data were reported with convergence limit in triplicate (Fig. 1).

\section{Experimental animals}

Thirty adult male albino rats, weighing $180-$ $200 \mathrm{~g}$, were obtained from the National Center for Radiation Research and Technology (NCRRT), Egyptian Atomic Energy Authority, Cairo, Egypt. The animals were kept in a well-ventilated animal house in isolated cages, and were maintained on a standard diet and provided water ad libitum. Before the beginning of the experiment, rats were kept under surveillance for one week to be acclimatized. They were maintained at a room temperature of $22 \pm 5^{\circ} \mathrm{C}$ under $12 \mathrm{hr}$ light dark cycles.

\section{Experimental design}

Rats were randomly divided into five groups (each of six rats): Group I (control), Group II (TP), Group III ( $\gamma$-irradiated), Group IV (TP + $\gamma$-irradiated) and Group V (TP $+\gamma$-irradiated $+\mathrm{TP})$. The irradiated rats were whole body exposed to acute single dose of $\gamma$-irradiation (8Gy). Groups II, IV and V received TP (200mlkg body weight, orally) (Mousavi et al., 2015) dissolved in saline for 7 days, then Groups IV and V were exposed to $\gamma$-irradiation in the $8^{\text {th }}$ day, one hour after $\gamma$-irradiation, Group V continued to receive TP for another 7 days. All rats were sacrificed $24 \mathrm{hr}$ after the last dose of TP. The investigation complies with the Guide for Care and Use of Laboratory Animals published by the US National Institutes of Health (NIH) and the study protocol was approved by the ethical committee of the NCRRT.

\section{Irradiation processing}

Irradiation processing was carried out at the NCRRT using a Canadian Gamma Cell-40, $\left({ }^{137} \mathrm{Cs}\right)$. Animals were submitted to whole body $\gamma$-irradiation at a dose level of $8 \mathrm{~Gy}$ delivered at a dose rate of $0.4319 \mathrm{~Gy} / \mathrm{min}$.

\section{Samples collection and preparation}

Animals were anaesthetized with urethane after over night fasting then sacrificed. Blood samples were obtained by heart puncture. Serum was separated by centrifugation at 3000rpm and stored at $-20^{\circ} \mathrm{C}$ until analysis. The brain was excised and a suitable weight of brain tissues $(0.5 \mathrm{~g})$ was homogenized in $5 \mathrm{ml}$ of ice-cold $0.1 \mathrm{M}$ phosphate buffer saline ( $\mathrm{pH}$ 7.4), then the homogenate was centrifuged and the supernatant was collected for further biochemical analysis. Brain tissue specimens were fixed in $10 \%$ buffered formalin solution for the histopathological investigation.

\section{Biochemical procedures}

Serum hepatic transaminases enzymes (alanine transaminase (ALT) and aspartate transaminase (AST)) activities as well as renal function (urea and creatinine) were assessed according to standard methods using obtainable commercial kits (Spectrum diagnostics, Cairo, Egypt). Lipid peroxidation was determined by quantifying MDA levels in tissue homogenates according to the method illustrated by Yoshioka et al. (1979). Also, activity of SOD in tissue homogenates was assessed according to Minami \& Yoshikawa (1979) method. The total antioxidant capacity (TAC) in brain tissue was measured using Randox total antioxidant status kit (UK) according to Miller et al. (1993). S100B and BDNF protein levels in serum and brain tissue respectively were quantified using a commercially existing enzymelinked immunosorbent assay (ELISA) kit (My Biosource, USA) according to the manufacturer's protocol. 


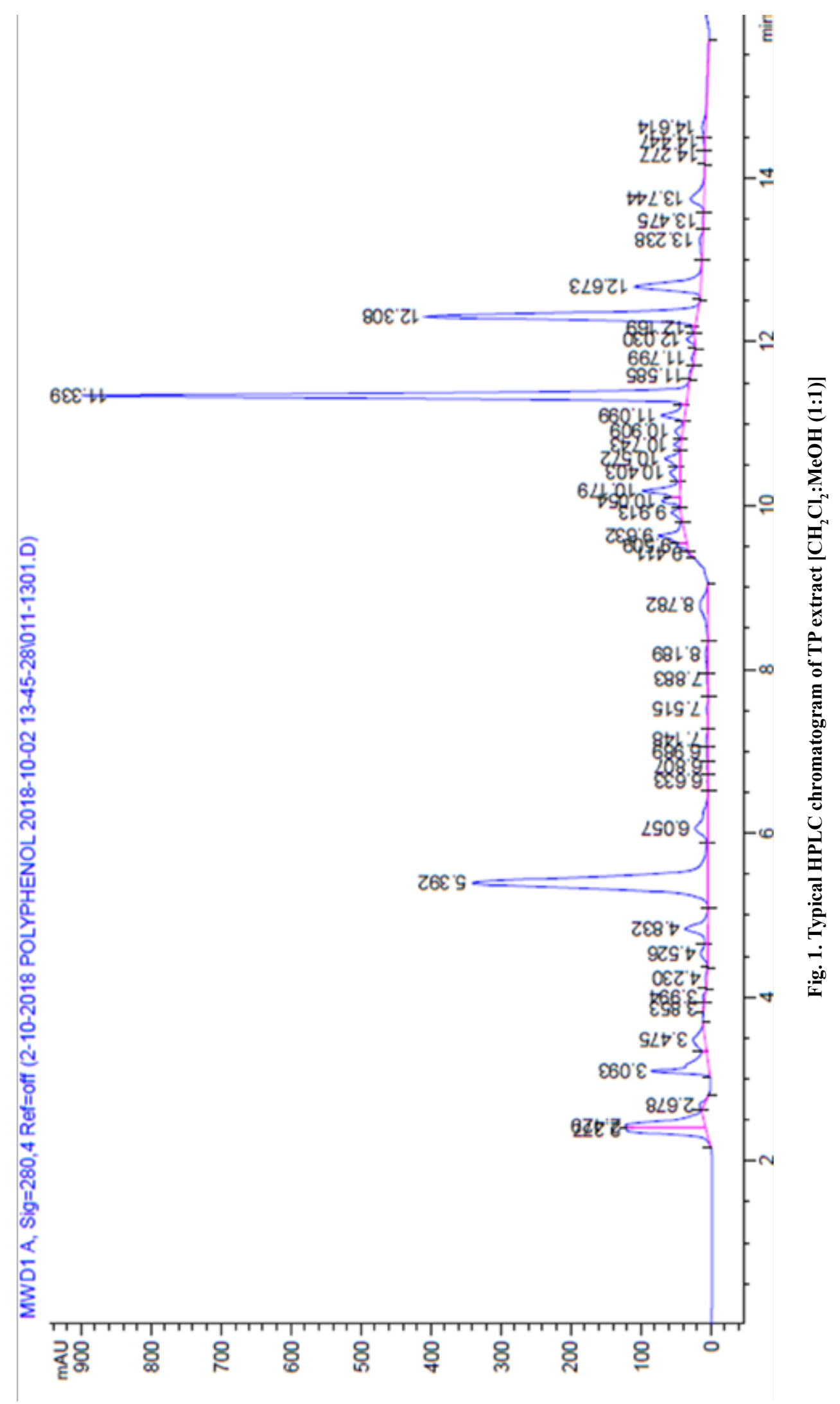

Egypt. J. Rad. Sci. Applic. 32, No.1 (2019) 


\section{Histopathological examination}

For the histopathological investigation, specimens of brain tissue were fixed in $10 \%$ buffered formalin solution followed by dehydration, cleating and embedding in paraffin. Paraffin sections of $5 \mu \mathrm{m}$ thickness were sliced and stained routinely with haematoxylin and eosin reagent, according to Bancroft \& Stevens (1996) and examined with light microscope.

\section{Statistical analysis}

Data were reported as means \pm standard error (SE). All results were statistically analyzed by one way analysis of variance (ANOVA) followed by a post hoc, least significant difference (LSD) test using Statistical Package for Social Science (SPSS) program version 15 . Results were considered statistically significant when $\mathrm{P}$ value $<0.05$.

\section{$\underline{\text { Results }}$}

Identification and quantification of phenolic compounds in TP extract

The HPLC chromatogram of $\mathrm{CH}_{2} \mathrm{Cl}_{2}-\mathrm{MeOH}$ (1:1) extract of the aerial parts of TP showed the presence of gallic acid, chlorogenic acid, catechin, caffeine, caffeic acid, ellagic acid, coumaric acid, vanillin, ferulic acid, naringenin, propyl gallate, 4',7-dihydroxy isoflavone, quercetin, and cinnamic acid as presented in Table 1. The structures of these compounds were illustrated in Fig. 2.

\section{Effect of TP extract on liver and renal functions}

Compared to control group, serum ALT and AST activities in $\gamma$-irradiated rats showed a significant increase $(\mathrm{P} \leq 0.001)$. Moreover, $\gamma$-radiation induced a significant increase in serum urea and creatinine levels $(\mathrm{P} \leq 0.001)$ (Table 2$)$.

Compared to $\gamma$-irradiated group, TP extract administration before $\gamma$-radiation induced a significant reduction in serum activities of ALT and AST $(\mathrm{P} \leq 0.01$ and $\mathrm{P}<0.05$, respectively), and serum levels of urea and creatinine $(\mathrm{P} \leq 0.001)$. In addition, TP extract treatment for additional one week after $\gamma$-radiation further reduced these parameters $(\mathrm{P} \leq 0.001$ and $\mathrm{P} \leq 0.01$, for $\mathrm{ALT}$ and AST respectively; $\mathrm{P} \leq 0.001$, for urea and creatinine) compared to $\gamma$-irradiated Group (Table 2).

Effect of TP extract on oxidative stress parameters

The exposure to $\gamma$-radiation caused a significant increase of MDA levels in brain tissue compared to control group $(\mathrm{P} \leq 0.001)$. Further, SOD activities and TAC levels in brain tissue markedly decreased in $\gamma$-irradiated rats $(\mathrm{P} \leq 0.001)$ (Table 3).

TABLE 1. Determination of polyphenols in Teucrium polium extract $\mathrm{CH}_{2} \mathrm{Cl}_{2}: \mathrm{MeOH}(1: 1)$ by using the proposed HPLC method (wavelength 280nm).

\begin{tabular}{lccc}
\hline Compounds & Retention time & Peak area & Conc. $(\boldsymbol{\mu g} / \mathbf{m l})$ \\
\hline Gallic acid & 3.093 & 545.72 & 35.94 \\
Chlorogenic acid & 3.475 & 365.60 & 24.18 \\
Catechin & 3.853 & 35.77 & 6.12 \\
Caffeine & 3.994 & 39.90 & 1.18 \\
Coffeic acid & 4.832 & 270.35 & 9.18 \\
Syringic acid & 5.239 & 0.00 & 0.00 \\
Rutin & 5.539 & 0.00 & 0.00 \\
Pyrocatechol & 5.741 & 0.00 & 0.00 \\
Ellagic acid & 6.633 & 10.25 & 0.74 \\
Coumaric acid & 7.515 & 23.09 & 0.53 \\
Vanillin & 8.189 & 58.55 & 2.09 \\
Ferulic acid & 8.782 & 203.05 & 4.43 \\
Naringenin & 9.328 & 0.00 & 0.00 \\
Propyl gallate & 10.179 & 394.57 & 9.87 \\
4 .7-Dihydroxy isoflavone & 10.401 & 182.46 & 4.86 \\
Quercetin & 10.571 & 165.16 & 13.81 \\
Cinnamic acid & 11.100 & 189.18 & 1.60 \\
\hline
\end{tabular}


<smiles>O=C(O)c1cc(O)c(O)c(O)c1</smiles>

Gallic Acid<smiles>COc1cc(C=O)ccc1O</smiles>

Vanillin<smiles>O=c1oc2c(O)c(O)cc3c(=O)oc4c(O)c(O)cc1c4c23</smiles><smiles>Cn1c(=O)c2c(ncn2C)n(C)c1=O</smiles>

Ellagic acid<smiles>CCCOC(=O)c1cc(O)c(O)c(O)c1</smiles>

Propyl Gallate<smiles>C1CCCCC1</smiles><smiles>[TeH]</smiles>

$\mathrm{COOH}$ Caffeine<smiles>CC(=O)O</smiles>

Chlorogenic acid<smiles>O=C(O)/C=C/c1ccc(O)c(O)c1</smiles>

Caffeic acid<smiles>O=C(O)/C=C/c1ccc(O)cc1</smiles>

Coumaric Acid<smiles>COc1cc(/C=C/C(=O)O)ccc1O</smiles>

Ferulic Acid<smiles>COc1cc(/C=C/C(=O)O)ccc1O</smiles>

Cinnamic Acid

$$
\text { Catechin }
$$<smiles>Cc1ccc(O)c(O)c1</smiles><smiles>O=c1c(-c2ccc(O)cc2)coc2cc(O)ccc12</smiles>

4'.7-Dihydroxy isoFlavone<smiles>O=c1c(O)c(-c2ccc(O)c(O)c2)oc2cc(O)cc(O)c12</smiles>

Quercetin

Fig. 2. Structure of compounds determined in $\mathrm{TP}$ extract $\mathrm{CH}_{2} \mathrm{Cl}_{2}: \mathrm{MeOH}(1: 1)$ by using the proposed $\mathrm{HPLC}$ method. 
TABLE 2. Effect of Teucrium polium extract on liver and renal functions against irradiation.

\begin{tabular}{lccccc}
\hline Parameters & Group I & Group II & Group III & Group IV & Group V \\
\hline ALT (U/L) & $21.00 \pm 1.73$ & $22.67 \pm 1.76$ & $50.00 \pm 6.66^{\mathrm{a}^{* * *} \mathrm{~b} * * *}$ & $28.67 \pm 2.03^{\mathrm{c}^{* *}}$ & $24.33 \pm 2.85^{\mathrm{c}^{* * *}}$ \\
AST (U/L) & $22.67 \pm 2.03$ & $24.33 \pm 2.03$ & $49.33 \pm 6.74^{\mathrm{a}^{* * * \mathrm{~b} * * *}}$ & $33.67 \pm 2.60^{\mathrm{c}^{*}}$ & $28.33 \pm 2.40^{\mathrm{c}^{* * *}}$ \\
Urea (mg/dl) & $41.00 \pm 2.31$ & $38.67 \pm 2.03$ & $75.33 \pm 2.03^{\mathrm{a}^{* * *} \mathrm{~b} * * *}$ & $47.00 \pm 2.08^{\mathrm{b}^{*} \mathrm{c}^{* * *}}$ & $42.33 \pm 2.03^{\mathrm{c}^{* * *}}$ \\
Creatinine (mg/dl) & $0.15 \pm 0.02$ & $0.15 \pm 0.01$ & $0.86 \pm 0.08^{\mathrm{a}^{* * * \mathrm{~b} * * *}}$ & $0.41 \pm 0.06^{\mathrm{ab}^{*} \mathrm{c}^{* * * *}}$ & $0.38 \pm 0.08^{\mathrm{a}^{* \mathrm{~b}^{*} \mathrm{c}^{* * *}}}$ \\
\hline
\end{tabular}

Group I (control), group II (TP), group III ( $\gamma$-irradiated), group IV (TP $+\gamma$-irradiated) and group V (TP $+\gamma$-irradiated $+\mathrm{TP})$. $n=6$ rats per group.

a: Significance vs control; b: Significance vs TP; c: Significance vs $\gamma$-irradiated

$*: \mathrm{P}<0.05 ; * *: \mathrm{P} \leq 0.01 ; * * *: \mathrm{P} \leq 0.001$

TABLE 3. Effect of Teucrium polium extract on oxidative stress parameters in brain against irradiation.

\begin{tabular}{lccccc}
\hline Parameters & Group I & Group II & Group III & Group IV & Group V \\
\hline MDA (U/mg protein) & $9.80 \pm 0.38$ & $8.90 \pm 0.67$ & $44.17 \pm 7.47^{\mathrm{a}^{* * \mathrm{~b}} \mathrm{~b} * * *}$ & $19.30 \pm 3.46^{\mathrm{c}^{* * *}}$ & $16.67 \pm 2.07^{\mathrm{c}^{* * *}}$ \\
SOD (U/mg protein) & $2.65 \pm 0.28$ & $3.10 \pm 0.21$ & $0.75 \pm 0.15^{\mathrm{a}^{* * *} \mathrm{~b} * * *}$ & $2.03 \pm 0.19^{\mathrm{b}^{* * \mathrm{c}^{* * *}}}$ & $2.07 \pm 0.32^{\mathrm{b}^{* * * *}}$ \\
TAC (U/mg protein) & $25.90 \pm 1.33$ & $29.37 \pm 1.85$ & $13.70 \pm 1.87^{\mathrm{a}^{* * * \mathrm{~b} * * *}}$ & $20.93 \pm 1.86^{\mathrm{b}^{* * \mathrm{c}^{* *}}}$ & $21.97 \pm 1.26^{6^{* \mathrm{c}^{* * *}}}$ \\
\hline
\end{tabular}

Group I (control), group II (TP), group III ( $\gamma$-irradiated), group IV (TP $+\gamma$-irradiated) and group V (TP $+\gamma$-irradiated $+\mathrm{TP})$. $\mathrm{n}=6$ rats per group.

a: Significance vs control; b: Significance vs TP; c: Significance vs $\gamma$-irradiated

$*: \mathrm{P}<0.05 ; * *: \mathrm{P} \leq 0.01 ; * * *: \mathrm{P} \leq 0.001$

TP extract administration before $\gamma$-radiation resulted in a significant reduction in MDA levels $(\mathrm{P} \leq 0.001)$, and a significant increase in SOD activities $(\mathrm{P} \leq 0.01)$ and TAC levels $(\mathrm{P}<0 \quad .05)$ compared to $\gamma$-irradiated control group. Moreover, TP extract treatment for additional one week after $\gamma$-radiation further reduced MDA levels $(\mathrm{P} \leq 0.001)$ and increased SOD activities $(\mathrm{P} \leq 0.01)$ and TAC levels $(\mathrm{P} \leq 0.01)$ compared to $\gamma$-irradiated control group (Table 3).

\section{Effect of TP extract on S100B and BDNF}

Serum S100B levels in $\gamma$-irradiated rats showed a significant increase compared to control group
$(\mathrm{P} \leq 0.01)$. Additionally, $\gamma$-radiation induced a significant decrease in BDNF levels in brain tissue $(\mathrm{P} \leq 0.001)$ (Table 4).

Compared to $\gamma$-irradiated group, TP extract administration before $\gamma$-radiation caused a significant reduction in serum S100B levels $(\mathrm{P}<$ 0.05 ), and a significant increase in brain BDNF levels $(\mathrm{P} \leq 0.001)$. Likewise, TP extract treatment for additional one week after $\gamma$-radiation further reduced S100B levels $(\mathrm{P}<0.05)$ and increased BDNF levels $(\mathrm{P} \leq 0.001)$ compared to $\gamma$-irradiated control group (Table 4).

TABLE 4. Effect of Teucrium polium extract on serum S100B and brain BDNF against irradiation.

\begin{tabular}{lccccc}
\hline Parameters & Group I & Group II & Group III & Group IV & Group V \\
\hline S100B (ng/ml) & $15.83 \pm 1.37$ & $14.17 \pm 1.12$ & $64.10 \pm 17.49^{\mathrm{a}^{* * *} \mathrm{~b} * *}$ & $33.10 \pm 1.99^{\mathrm{c}^{*}}$ & $28.67 \pm 6.73^{\mathrm{c}^{*}}$ \\
$\begin{array}{l}\text { BDNF (ng/mg } \\
\text { protein) }\end{array}$ & $115.73 \pm 2.01$ & $116.50 \pm 3.39$ & $60.03 \pm 5.38^{\mathrm{a}^{* * * *} \mathrm{~b}^{* * *}}$ & $91.03 \pm 2.72^{\mathrm{a}^{* *} \mathrm{~b}^{* * * \mathrm{c}^{* * * *}}}$ & $101.87 \pm 4.86^{\mathrm{a}^{* \mathrm{~b}^{*} \mathrm{c}^{* * *}}}$ \\
\hline
\end{tabular}

Group I (control), group II (TP), group III ( $\gamma$-irradiated), group IV (TP $+\gamma$-irradiated) and group V (TP $+\gamma$-irradiated + TP). $n=6$ rats per group.

a: Significance vs control; b: Significance vs TP; c: Significance vs $\gamma$-irradiated

$*: \mathrm{P}<0.05 ; * *: \mathrm{P} \leq 0.01 ; * * * \mathrm{P} \leq 0.001$ 


\section{Histopathological examination}

For supplementary description of the brain injury induced by $\gamma$-radiation and the effect of TP extract administration, histopathological examination of brain tissue was done. No histopathological alteration and normal histological structure of the brain tissue were recorded in control and TP groups (Fig. 3 a, b; Fig. 4 a, b; Fig. 5 a, b; Fig. 6 a, b and Fig. 7 $\mathrm{a}, \mathrm{b})$. In contrast, histological examination of brain tissue from $\gamma$-irradiated animals revealed nuclear pyknosis and degeneration in most of the neurons associated with congestion in the blood vessels in cerebral cortex (Fig. 3 c, d). In regard to subiculum in hippocampus, irradiated rats exhibited nuclear pyknosis and degeneration in some of the neurons (Fig. $4 \mathrm{c}$ ). In the same group fascia dentata and hilus in the hippocampus also displayed nuclear pyknosis and degeneration in some of the neurons (Fig. 5 c). Striatum of irradiated animal brains presented multiple focal eosinophilic plagues (Fig. $6 \mathrm{c}$ ). In addition, the histopathological examination of cerebellum revealed nuclear pyknosis and degeneration in some of the Purkenji cells (Fig. 7 c). TP extract administration before irradiation reverse radiation-induced injury in cerebral cortex (Fig.
3 e). However, the group of rats treated with TP extract for additional one week after $\gamma$-radiation still had nuclear pyknosis and degeneration in the neurons in cerebral cortex (Fig. $3 \mathrm{f}$ ). Subiculum in hippocampus showed normal histopathological findings in the two groups either administered $\mathrm{TP}$ extract before $\gamma$-radiation or treated with TP extract for additional one week after $\gamma$-radiation (Fig. 4 d, e). Nuclear pyknosis and degeneration were detected in some neurons in TP extract administrated group before irradiation (Fig. $5 \mathrm{~d})$ and in some few neurons in group treated with TP extract for additional one week after $\gamma$-radiation (Fig. 5 e) in fascia dentata and hilus in the hippocampus. TP extract administration before radiation restored striatum portion (Fig. $6 \mathrm{~d})$. On the other hand, nuclear pyknosis and degeneration in some few neurons in striatum portion were showed in rats treated with TP extract for additional one week after $\gamma$-radiation (Fig. 6 e). There were no histopathological alterations and normal histological structure of the neurons in cerebellum of the brain of either TP extract administrated rats before $\gamma$-radiation or rats treated with TP extract for additional one week after $\gamma$-radiation (Fig. 7 d, e).

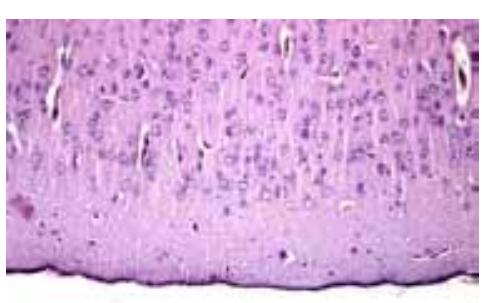

(a)

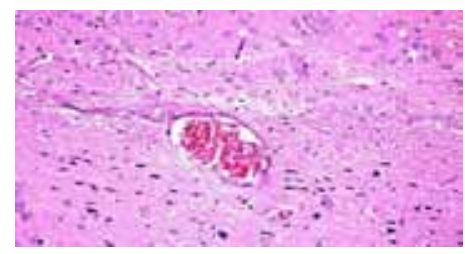

(d)

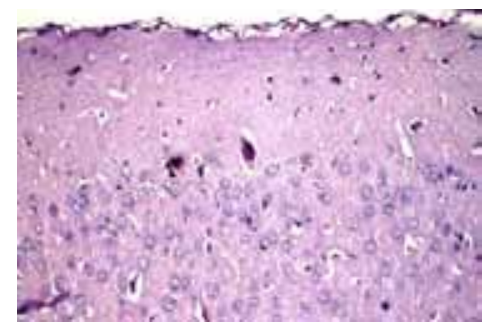

(b)

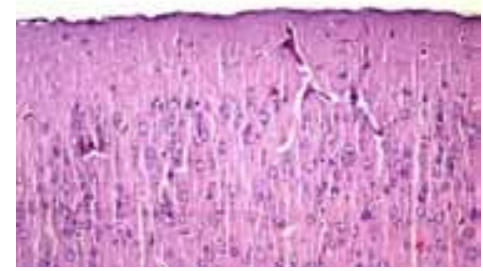

(e)

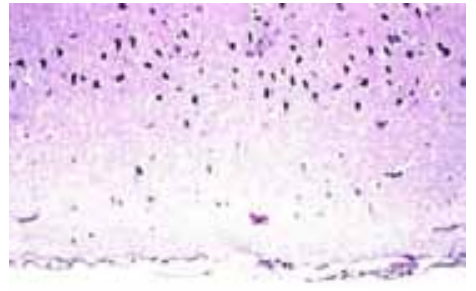

(c)

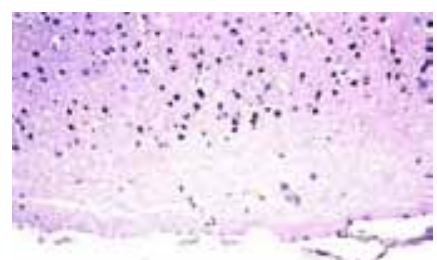

(f)

Fig. 3. Histopathological findings of cerebral cortex: (a) There were no histopathological alteration and normal histological structure of the neurons, (b) There were no histopathological alteration and normal histological structure of the neurons, (c \& d) Nuclear pyknosis and degeneration were detected in most of the neurons (c) associated with congestion in the blood vessels (d), (e) There were no histopathological alteration and normal histological structure of the neurons, (f) There were nuclear pyknosis and degeneration in the neurons [where, (a) control group, (b) TP group, (c) and (d) $\gamma$-irradiated group, (e) TP $+\gamma$-irradiated group and (f) TP $+\gamma$-irradiated + TP group]. 


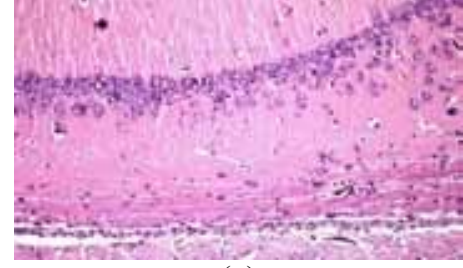

(a)

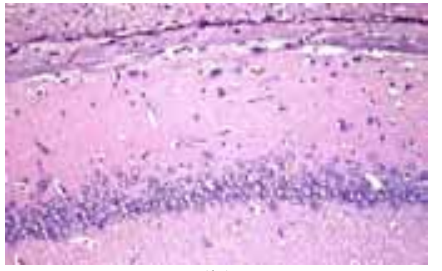

(b)

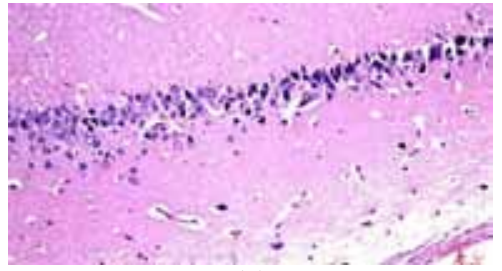

(c)

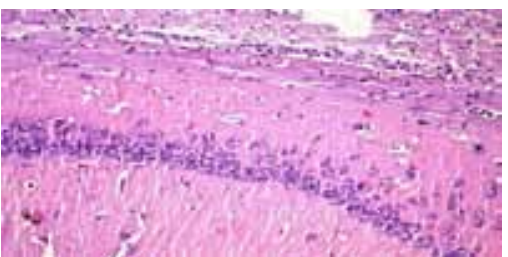

(d)

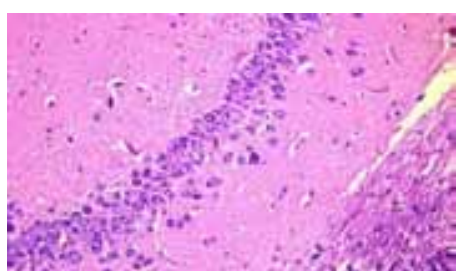

(e)

Fig. 4. Histopathological findings of subiculum in the hippocampus: (a) There were no histopathological alteration and normal histological structure of the neurons, (b) There were no histopathological alteration and normal histological structure of the neurons, (c) Nuclear pyknosis and degeneration were recorded in some of the neurons, (d) There were no histopathological alteration and normal histological structure of the neurons, (e) There were no histopathological alteration and normal histological structure of the neurons [where, (a) control group, (b) TP group, (c) $\gamma$-irradiated group, (d) TP $+\gamma$-irradiated group and (e) $\mathrm{TP}+\gamma$-irradiated + TP group].

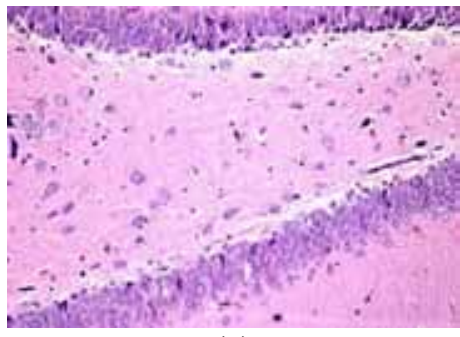

(a)

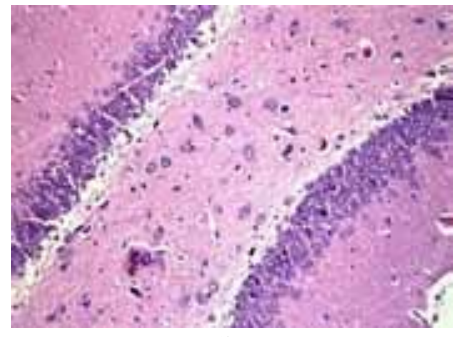

(b)

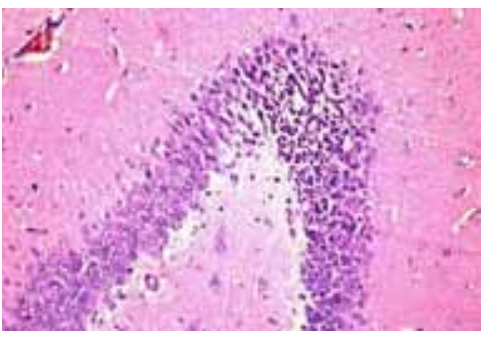

(c)

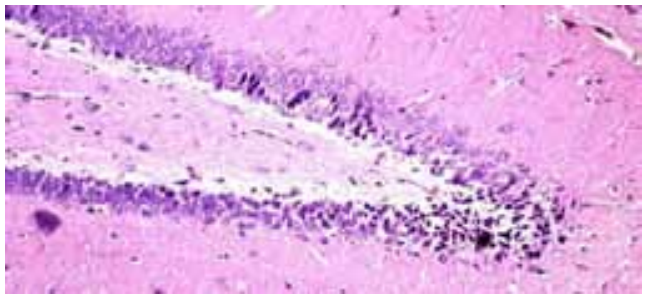

(d)

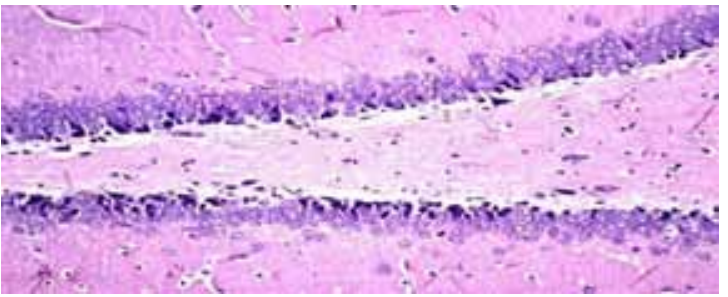

(e)

Fig. 5. Histopathological findings of fascia dentata and hilus in the hippocampus: (a) There were no histopathological alteration and normal histological structure of the neurons, (b) There were no histopathological alteration and normal histological structure of the neurons, (c) Some of the neurons showed nuclear pyknosis and degeneration, (d) Nuclear pyknosis and degeneration were detected in some neurons, (e) Some few neurons showed nuclear pyknosis and degeneration [where, (a) control group, (b) TP group, (c) $\gamma$-irradiated group, (d) TP $+\gamma$-irradiated group and (e) TP $+\gamma$-irradiated + TP group]. 


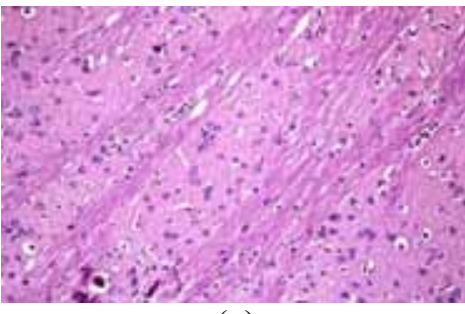

(a)

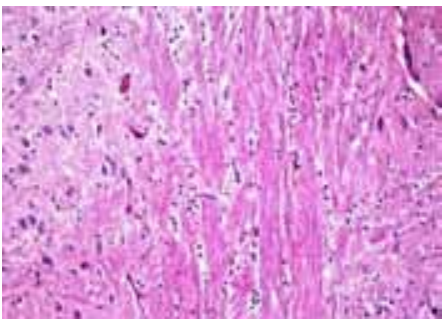

(b)

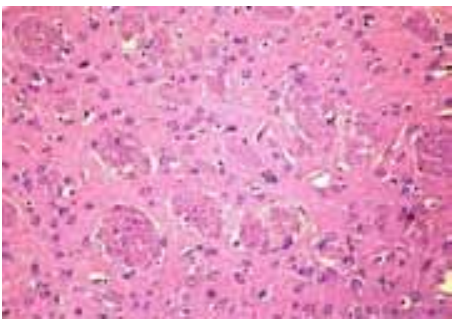

(c)

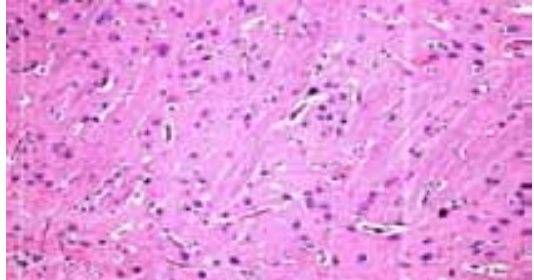

(d)

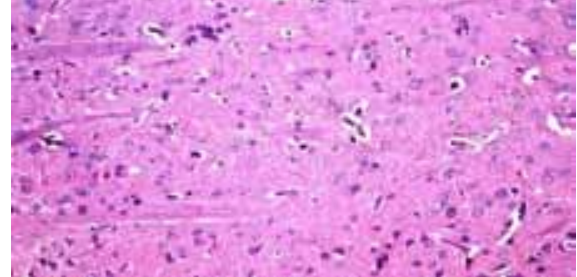

(e)

Fig. 6. Histopathological findings of striatum: (a) There were no histopathological alteration and normal histological structure of the neurons, (b) There were no histopathological alteration and normal histological structure of the neurons, (c) Multiple focal eosinophilic plagues were showed, (d) There were no histopathological alteration and normal histological structure of the neurons, (e) There were nuclear pyknosis and degeneration in some few neurons [where, (a) control group, (b) TP group, (c) $\gamma$-irradiated group, (d) TP + $\gamma$-irradiated group and (e) TP $+\gamma$-irradiated + TP group].

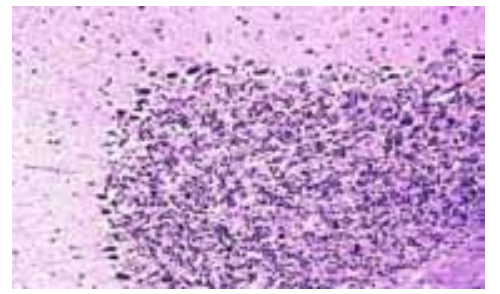

(a)

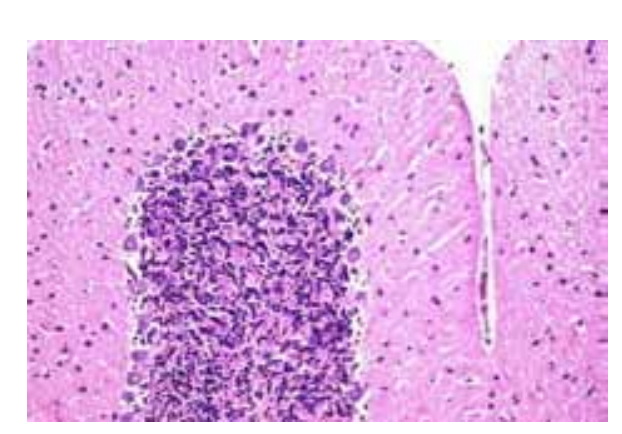

(d)

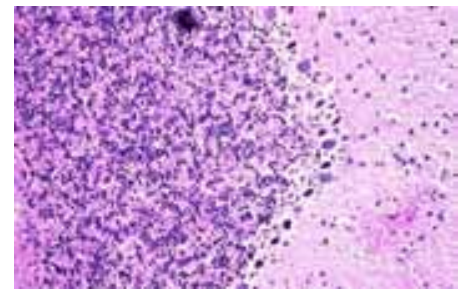

(b)

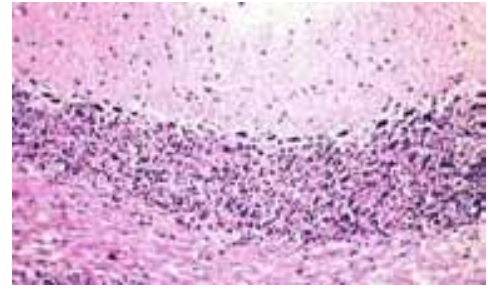

(c)

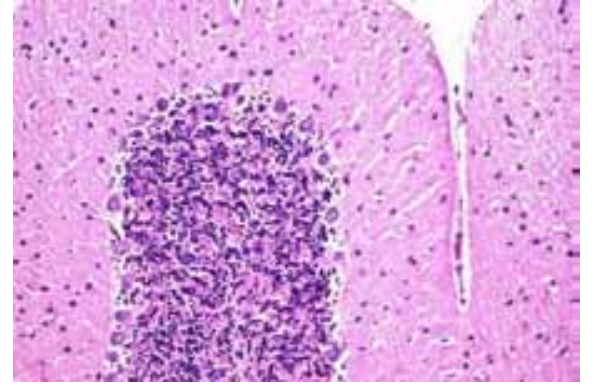

(e)

Fig. 7. Histopathological findings of cerebellum: (a) There were no histopathological alteration and normal histological structure of the neurons, (b) There were no histopathological alteration and normal histological structure of the neurons, (c) There were nuclear pyknosis and degeneration in some of the Purkenji cells, (d) There were no histopathological alteration and normal histological structure of the neurons, (e) There were no histopathological alteration and normal histological structure of the neurons [where, (a) control group, (b) TP group, (c) $\gamma$-irradiated group, (d) TP $+\gamma$-irradiated group and (e) TP $+\gamma$-irradiated + TP group]. 


\section{Discussion}

Radiation treatment is an important therapeutic choice in the management of various cancers. Normal healthy tissues are also commonly affected during this treatment option (Demirel et al., 2011). A comprehensive understanding of the molecular and cellular processes underlying radiobiological responses is presently developing (Calabrese, 2015 ) and there is still ambiguity surrounding the nature of biological responses to various doses of ionizing radiation, chiefly within the situation of the complicated and multifaceted CNS or newly born differentiating cells that integrate into the hippocampal network, manifesting as longer term functional shortfalls (Parihar \& Limoli, 2013). Inflammation, protection, defense and repair of neurobiological mechanisms comprise of networks of cells and molecular mediators that react to alterations in homeostasis (Zhang et al., 2016).

A recent published data meta-analysis suggests an overall significant effect of oxidative injury in response to ionizing radiation, mostly on the braincells. Interestingly, there was a significant heterogeneity in effect sizes among species and cell types crosswise the body (Einor et al., 2016), underlining the huge variability of responses to ionizing radiation. Ionizing radiation leads to a cascade of events that activates microglia, the brains innate immune effect or cells, which exhibit striking morphological and functional plasticity in response to insults which start to release chemokines and pro-inflammatory cytokines which may cause oxidative stress in the brain. These immune cells infiltrated into the brain tissue and in turn produce ROS which trigger more microglia and more immune cells that can increase the oxidative stresslevel (Ballesteros-Zebadúa et al., 2012). Cooperatively, activated microglia can act through mechanisms such as the nuclear factor kappa B pathway to release ROS, reactive nitrogen species and pro-inflammatory cytokines such astumor necrosis factor- $\alpha$, interleukin (IL)$1 \beta$ and IL- 6 , or through mitogen-activated protein kinase signaling pathways that trigger NADPH to establish neuroinflammation (Han \& Choi, 2012; Yuste et al., 2015; Sharma \& Nehru, 2016 and Ye et al., 2016).

Certainly, neuroinflammation and oxidative stress have been involved in numerous disorders of CNS, particularly Alzheimer's disease (Jiang et al., 2016 and Levy Nogueira et al., 2016) and Parkinson's disease (Aquilano et al., 2008; Wang et al., 2013 and Sharma \& Nehru, 2016), potentiating cellular damage and pathology. Neuronal injury induced by radiationis one of the most prominent and serious side effects of cranial radiation therapy, which leads to a variety of clinical manifestations (Laack \& Brown, 2004). In the same line, the existence of cognitive decline in patients after a clinical high dose of irradiation exposure has led to a research emphasis on the hippocampal microenvironment and its population of mature cells and proliferating progenitor cells in the dentate gyrus subgranular zone. This neurogenesis region is particularly ionizing radiation sensitive (Rola et al., 2008), as mitotic cells are radiosensitive at the cell cyclestages between the G2 and M phase (Marples et al., 2003 and Todorovic et al., 2015). These findings are in agreement with other reports demonstrating that radiation stimulates a premature aging process in the brain and accelerates and/or aggravates the chronic degenerative disorders feature onset for elderly (Dietrich et al., 2008 and Hua et al., 2012).

The curative manipulation of plants dates back to prehistoric eras (Mousavi et al., 2015). Preceding studies illustrated the potential role of different traditional neuroprotective herbal extracts/isolated phytochemicals in prevention of neurodegeneration. Moreover, an evidence exists for the neuromodulatory effects of phytochemicals and suggests that these phytochemicals may induce beneficial outcomes on the vascular system leading to alteration in cerebrovascular blood flow and neuronal function modulation. Therefore, natural products may harmonize very well for the neuronal injury treatment ( $\mathrm{Li}$ et al., 2003). Since oxidative stress is correlated with dysfunction in mitochondrial and endoplasmic reticulum, which includes apoptosis and protein misfolding in neurons, phytochemical based antioxidants may have neuroregenerative and neuroprotective roles by retreating or reducing cellular damage and by slowing neuronal cell loss progression (Moosmann \& Behl, 2002).

In the present study, TP extract exhibits, to certain extent, preventive as well as therapeutic role in brain damage induced by ionizing radiation. In accordance with this, it has been reported that TP protects against memory losses in scopolamineand diabetes-induced memory impairment models (Orhan \& Aslan, 2009; Hasanein \& 
Shahidi, 2012). The prominent activity of TP in memory augmentation could be related to its terpenic and flavonoid compounds (Bahramikia \& Yazdanparast, 2012). In the present study, it was indicated that TP extract significantly reduced lipid peroxidation and increased SOD activity and TAC in the brain tissue. These obvious TP protective effects against oxidative stress observed in this study are consistent with the formerly published reports (Ljubuncic et al., 2006 and Zabihi et al., 2018).In this respect, a TP methanolic extract protected red blood cells against hydrogen peroxide-induced lipid peroxidation (Suboh et al., 2004). In another study, Kadifkova Panovska et al. (2005) proved that the extracts of TP prepared using different organic solvents (diethyl ether, ethyl acetate, and n-butanol) were effective inhibitors of $\beta$-carotene oxidation. In an earlier study, it was shown that the extracts prepared from TP suppressed lipid peroxidation in vitro (Qabaha, 2013).Also, previous studies indicated that TP prevents oxidative damage in the liver (Panovska et al., 2007), stomach (Mehrabani et al., 2009), and pancreas (Esmaeili et al., 2009). It was suggested that this high antioxidant activity is owing to the phenolic compounds detected in this herb such as hydroxybenzoic acid derivatives, ferulic acid, caffeic acid, and flavonoid derivatives such as luteolin and quercetin (Proestos et al., 2006). In concurrence with this, the results of the current study demonstrated the presence of many phenolic compounds in TP extract.

It has been described that TP (200 and 400mg/ $\mathrm{kg}$ ) prevented the detrimental effects of diabetes on passive avoidance memory, but $100 \mathrm{mg} / \mathrm{kg}$ of TP did not have any positive effect on the memory deficits induced by diabetes (Hasanein \& Shahidi, 2012). On the other hand, in the study of Mousavi et al. (2015) memory deficits were prevented by all three doses of TP $(100,200$, and $400 \mathrm{mg} / \mathrm{kg}$ ). Although the exact mechanism of TP in preventing learning and memory deficits is still in debate, Mousavi et al. (2015) suggested that protection against oxidative stress was possibly involved in the learning and memory enhancing properties of the extract since they observed that all three doses of TP significantly reduced lipid peroxidation in the hippocampus and cerebral cortex. In the present study, the chosen dose was $200 \mathrm{mg} / \mathrm{kg}$ and was effective in our model. Mousavi et al. (2015) also revealed that the high extract dose also increased total concentration of thiol in hippocampal tissues.
In the present study, higher doses were avoided as recommended by Baradaran et al. (2013) and Rasekh et al. (2005). In contrast to the beneficial effects of TP, which were mentioned and seen in the present study and in Mousavi et al. (2015) study, hepatotoxic and nephrotoxic effects of the plant have also been described (Khleifat et al., 2002 and Rafieian-Kopaei \& Nasri, 2013) and should be considered before reaching a final conclusion about the efficacy of this plant. In this context, testing of liver and renal functions was performed in the present study to check on these toxic effects and the results illustrated that TP has no hepatic or renal toxicity, but on the contrary of that, it ameliorated the damaging effect of radiation occurred in liver and kidney.

It has been suggested that restoration of the neuronal and synaptic networks in the injured brain is obligatory for the brain functions recovery. It was once trusted that nerve regeneration in the mammalian CNS was irreversible, but recently it has become obvious that damaged neurons regenerate in an active process under occurrence of stimulatory substances such as nerve growth factor and BDNF (Filbin, 2000). In addition to anti-oxidation, TP could alleviate RIBI through regulating BDNF. BDNF was demonstrated to protect the cells against oxidative attack, inhibit apoptosis, and encourage the recovery function of damaged neurons (Grant et al., 2005). Decrease levels of BDNF were observed both in serum and in hippocampus after exposure of brains to ionizing radiation (Forbes et al., 2013 and Oh et al., 2013).

Severe BDNF deficiency was also detected in diabetic neuropathies in brain with depressive behavior through down regulation of levels of peroxisome proliferator-activated receptor gamma (PPAR $\gamma)$ in the hippocampus (Patel, 2016). Most importantly, Sonic Hedgehog (Shh) is one of the putative signaling molecules, which is implicated in the regulation of CNS polarity and neural patterning (Machold \& Fishell, 2002). Shh pathway activation is known to upregulates two important factors, BDNF and vascular endothelial growth factor. Shh signaling attenuates the oxidative stress effect on cortical neurons and has potential role in neurodegenerative disorders (Patel, 2016).

Apart from its documented neurotrophic actions and anti-apoptotic properties, anti- 
oxidative effects of BDNF may also contribute considerably to its protective characteristics in various experimental models mimicking neurodegenerative situations, which have gained less attention. In cultured rat's hippocampal neurons, BDNF increases the glutathione reductase and SODs expression levels (Mattson et al., 1995). Furthermore, BDNF may exert its protective effects by regulating superoxide anion homeostasis during an experimental model of temporal lobe status epilepticus (Tsai et al., 2012). Moreover, BDNF also diminishes the level of tyrosine nitration, an indicator for oxidative protein damage (Lee et al., 2009).

Neurons appear capable of reorganizing and repairing connections after primary and secondary brain damage in TBI. The reduction of this progressive neural dysfunction could be achieved using rationally targeted therapies that target mitochondrial damage, proteolysis, and cytoskeletal alteration, or neurotrophic factors such as BDNF that can facilitate reconnection in TBI (Buki \& Povlishock, 2006). BDNF is one of the most important neurotrophin factors in the brain, and the hippocampus can potentially recover from dendritic retraction throughout its expression without any neurons discernable loss (Conrad et al., 2008). For instance, induction of BDNF and activation of its intracellular receptor tropomycin receptor kinase $\mathrm{B}$ ( TrkB) can produce neural regeneration, reconnection, and dendritic sprouting, and can increase synaptic efficacy (Lipsky \& Marini, 2007 and Ola et al., 2014). In addition, low levels of BDNF were correlated with smaller hippocampus and poorer memory, even after controlling the variation related to age (Erickson et al., 2010). Reduced production of BDNF caused by obesity and hyperglycaemia could be harmful to neuronal process and functions leading to neurodegenerative diseases development (Franco-Robles et al., 2014). It was clearly demonstrated that BDNF reduction leading to neuronal atrophy and finally death (Ghadernezhad et al., 2016).

In the study of Zhang et al. (2016), they found that impairments in BDNF signaling and hippocampal neurogenesis induced by whole body irradiation were well associated with impaired learning and performance of memory as determined by the Morris water maze (MWM) and passive avoidance tests.
The first human TBI study of S100B as a serum biomarker of brain injury assessment was carried out by Ingebrigtsen et al. (1995) in 1995, although increased levels of S100B in cerebrospinal fluid following various neurological disorders had been formerly described in patients by Sindic et al. (1982) in 1982. Afterward, S100B was shown to be sensitive enough to distinguish and measure different traumatic intracranial lesions, including cerebral contusions (Raabe et al., 1998), subdural hematomas and traumatic subarachnoid hemorrhages (Romner et al., 2000), as well as epidural hematomas (Unden et al., 2005). While several reviews now exist, emphasizing S100B role in both mild (Unden \& Romner, 2010) and moderate-to-severe TBI (Mercier et al., 2013), new features have progressed in this field for instance the finding of S100B transportation through the newly discovered glymphatic system (Plog et al., 2015), implementation of the Scandinavian guidelines for TBI merging S100B (Unden et al., 2015) and improved kinetic modeling of S100B release from the injured brain (Ercole et al., 2016).

S100 proteins can act both intracellularly as regulators and extracellularly as signaling proteins, they can be secreted or released after cell injury and regulate cell activities as transmitters. The extracellular value of S100B is also quite fascinating because the effect and physiological functions of S100B have been shown to be concentration dependent, where lower concentrations (nanomolar levels) are beneficial and higher concentrations (micromolar levels) are correlated to harmful effects (Rothermundt et al., 2003 and Van Eldik \& Wainwright, 2003). Accelerating extracellular S100B levels have been shown to result in neuronal dysfunction or cell death due to an inflammatory response that stimulates astrocytes and microglia to recruit and produce pro-inflammatory cytokines with a subsequent increase of the extracellular levels of calcium and activation of nitric oxide, with harmful effects typically as in ionizing radiation injury (Hu et al., 1997 and Koppal et al., 2001). The diverse effects of S100B have been suggested to depend on the receptor for advanced glycation end-products (RAGE), which is upregulated by S100B levels and may cause pro-inflammatory gene activation (Donato et al., 2013), although much is still unknown about how S100B exerts its biochemical properties.

The results of the present study showed that 
S100B increased in RIBI and attenuated by the administration of TP and may be one of the mechanisms of its amelioration of the injury.

Histopathological findings confirmed the biochemical analysis and showed the amelioration effects of TP in different regions of brain.

\section{Conclusion}

Administration of TP extract might ameliorate RIBI by the attenuation of oxidative stress, the regulation of BDNF and suppression of S100B. The administration of TP before and after irradiation seems to be more effective than its administration only before irradiation. Therefore, it may be used to maximize the clinical use of radiotherapy in the treatment of various tumors located in or close to the CNS, as well as, in management of other brain disorders without side effects.

Acknowledgments: The authors are kindly appreciative to the staff members of gamma irradiation unit at the NCRRT for their generous support in carrying out the experimental irradiation. In addition, we are indebted to Dr. Mohamed-Elamir F. Hegazy, Associate Professor of Natural Products Chemistry, Phytochemistry Department, Division of Pharmaceutical and Drug Industries, National Research Center, Giza, Egypt, for his essential role in preparing the extract. We also, thank Prof. Adel B. Kholoussy, (PhD), Professor at the Pathology Department, Faculty of Veterinary Medicine, Cairo University, Egypt, for his assistance in examining and interpreting the histopathology aspects of this work.

Disclosure of interest: The authors report no conflicts of interest.

Financial support: This study is not funded.

\section{References}

Abdollahi, M., Karimpour, H. and Monsef-Esfehani, H.R. (2003) Antinociceptive effects of Teucrium polium L. total extract and essential oil in mouse writhing test. Pharmacol Res. 48(1), 31-35.

Aquilano, K., Baldelli, S., Rotilio, G. and Ciriolo, M.R. (2008) Role of nitric oxide synthases in Parkinson's disease: A review on the antioxidant and antiinflammatory activity of polyphenols. Neurochem.
Res. 33, 2416-2426.

Bahramikia, S. and Yazdanparast, R. (2012) Phytochemistry and medicinal properties of Teucrium polium L. (Lamiaceae). Phytother. Res. 26(11), 1581-1593.

Ballesteros-Zebadúa, P., Chavarria, A., Celis, M.A., Paz, C. and Franco-Pérez, J. (2012) Radiationinduced neuroinflammation and radiation somnolence syndrome. CNS Neurol Disord Drug Targets, 11(7), 937-949.

Bancroft, J.D. and Stevens, A.E. (1996) "Theory and Practice of Histological Techniques". $4^{\text {th }}$ ed. Edinburgh: Churchill Livingstone, 766p.

Baradaran, A., Madihi, Y., Merrikhi, A., RafieianKopaei, M., Nematbakhsh, M., Asgari, A., Khosravi, Z., Haghighian, F. and Nasri, H. (2013) Nephrotoxicity of hydroalcoholic extract of Teucrium polium in Wistar rats. Pak. J. Med. Sci. 29(1) Suppl, 329-333.

Bekinschtein, P., Cammarota, M., Katche, C., Slipczuk, L., Rossato, J.I., Goldin, A., Izquierdo, I. and Medina, J.H. (2008) BDNF is essential to promote persistence of long-term memory storage. Proc. Natl. Acad. Sci. USA, 105(7), 2711-2716.

Buki, A. and Povlishock, J.T. (2006) All roads lead to disconnection - traumatic axonal injury revisited. Acta Neurochir. 148, 181-194.

Calabrese, E.J. (2015) Hormesis within a mechanistic context. Homeopathy, 104(2), 90-96.

Calik, M., Abuhandan, M., Sonmezler, A., Kandemir, H., Oz, I., Taskin, A., Selek, S. and Iscan, A. (2013) Elevated serum S-100B levels in children with temporal lobe epilepsy. Seizure, 22(2), 99-102.

Caruso, C., Carcaterra, M. and Donato, V. (2013) Role of radiotherapy for high grade gliomas management. J. Neurosurg. Sci. 57(2), 163-169.

Chaves, M.L., Camozzato, A.L., Ferreira, E.D., Piazenski, I., Kochhann, R., Dall'Igna, O., Mazzini, G.S., Souza, D.O. and Portela, L.V. (2010) Serum levels of S100B and NSE proteins in Alzheimer's disease patients. J. Neuroinflammation, 7, 6 .

Conrad, K.L., Tseng, K.Y., Uejima, J.L., Reimers, J.M., Heng, L.J., Shaham, Y., Marinelli, M. and Wolf, 
M.E. (2008) Formation of accumbens GluR2lacking AMPA receptors mediates incubation of cocaine craving. Nature, 454, 118-121.

Couladis, M., Tzakou, O., Verykokidou, E. and Harvala, C. (2003) Screening of some Greek aromatic plants for antioxidant activity. Phytother. Res. 17(2), 194195.

Demirel, U., Harputluoglu, M.M., Us, S.B., Kaya, E., Sahin, N., Aydin, N.E., Gursoy, S., Bilgic, Y., Demirel, M., Bulut, T., Selcuk, E.B. and Aladag, M. (2011) The effects of Teucrium polium on ionizing radiation-induced intestinal damage in rats. Acta Gastroenterol. Belg. 74(4), 491-496.

Dietrich, J., Monje, M., Wefel, J. and Meyers, C. (2008) Clinical patterns and biological correlates of cognitive dysfunction associated with cancer therapy. Oncologist, 13, 1285-1295.

Donato, R. (2001) S100: A multigenic family of calcium-modulated proteins of the EF-hand type with intracellular and extracellular functional roles. Int. J. Biochem. Cell. Biol. 33(7), 637-668.

Donato, R., Cannon, B.R., Sorci, G., Riuzzi, F., Hsu, K., Weber, D.J. and Geczy, C.L. (2013) Functions of S100 proteins. Curr. Mol. Med. 13, 24-57.

Dong, X., Luo, M., Huang, G., Zhang, J., Tong, F., Cheng, Y., Cai, Q., Dong, J., Wu, G. and Cheng, J. (2015) Relationship between irradiation-induced neuro-inflammatory environments and impaired cognitive function in the developing brain of mice. Int. J. Radiat. Biol. 91(3), 224-239.

Egea-Guerrero, J.J., Murillo-Cabezas, F., GordilloEscobar, E., Rodríguez-Rodríguez, A., EnamoradoEnamorado, J., Revuelto-Rey, J., Pacheco-Sánchez, M., León-Justel, A., Domínguez-Roldán, J.M. and Vilches-Arenas, A. (2013) S100B protein may detect brain death development after severe traumatic brain injury. J. Neurotrauma, 30(20), 1762-1769.

Einor, D., Bonisoli-Alquati, A., Costantini, D., Mousseau, T.A. and Møller, A.P. (2016) Ionizing radiation, antioxidant response and oxidative damage: A meta-analysis. Sci. Total Environ. 548549, 463-471.

Ercole, A., Thelin, E.P., Holst, A., Bellander, B.M. and Nelson, D.W. (2016) Kinetic modelling of serum
S100b after traumatic brain injury. BMC Neurol. 16, 93.

Erickson, K.I., Prakash, R.S., Voss, M.W., Chaddock, L., Heo, S., McLaren, M., Pence, B.D., Martin, S.A., Vieira, V.J., Woods, J.A., McAuley, E. and Kramer, A.F. (2010) Brain-derived neurotrophic factor is associated with age-related decline in hippocampal volume. J. Neurosci. 30(15), 5368-5375.

Esmaeili, M.A. and Yazdanparast, R. (2004) Hypoglycaemic effect of Teucrium polium: Studies with rat pancreatic islets. J. Ethnopharmacol. 95(1), 27-30.

Esmaeili, M.A., Zohari, F. and Sadeghi, H. (2009) Antioxidant and protective effects of major flavonoids from Teucrium polium on beta-cell destruction in a model of streptozotocin-induced diabetes. Planta Med. 75, 1418-1420.

Filbin, M.T. (2000) Axon regeneration: Vaccinating against spinal cord injury. Curr. Biol. 10(3), R100-R103.

Forbes, M.E., Paitsel, M., Bourland, J.D. and Riddle, D.R. (2013) Systemic effects of fractionated, wholebrain irradiation in young adult and aging rats. Radiat. Res. 180(3), 326-333.

Franco-Robles, E., Campos-Cervantes, A., MurilloOrtiz, B.O., Segovia, J., López-Briones, S., Vergara, P., Pérez-Vázquez, V., Solís-Ortiz, M.S. and Ramírez-Emiliano, J. (2014) Effects of curcumin on brain-derived neurotrophic factor levels and oxidative damage in obesity and diabetes. Appl. Physiol. Nutr. Metab. 39(2), 211-218.

Galati, E.M., Mondello, M.R., D’Aquino, A., Miceli, N., Sanogo, R., Tzakou, O. and Monforte, M.T. (2000) Effects of Teucrium divaricatum Heldr. ssp. divaricatum decoction on experimental ulcer in rats. J. Ethnopharmacol. 72(1-2), 337-342.

Ghadernezhad, N., Khalaj, L., Pazoki-Toroudi, H., Mirmasoumi, M. and Ashabi, G. (2016) Metformin pretreatment enhanced learning and memory in cerebral forebrain ischaemia: The role of the AMPK/ BDNF/P70SK signalling pathway. Pharm. Biol. 54(10), 2211-2219.

Gharaibeh, M.N., Elayan, H.E. and Salhab, A.S. (1988) Hypoglycemic effects of Teucrium polium. J. Ethnopharmacol. 24(1), 93-99. 
Grant, M.M., Barber, V.S. and Griffiths, H.R. (2005) The presence of ascorbate induces expression of brain derived neurotrophic factor in SH-SY5Y neuroblastoma cells after peroxide insult, which is associated with increased survival. Proteomics. 5(2), 534-540.

Han, J.E. and Choi, J.W. (2012) Control of JNK for an activation of NADPH oxidase in LPS-stimulated BV2 microglia. Arch. Pharm. Res. 35(4), 709-715.

Hasanein, P. and Shahidi, S. (2012) Preventive effect of Teucrium polium on learning and memory deficits in diabetic rats. Med. Sci. Monit. 18(1), BR41BR46.

Hassan, H.A., Hafez, H.S. and Goda, M.S. (2013) Mentha piperita as a pivotal neuro-protective agent against gamma irradiation induced DNA fragmentation and apoptosis: Mentha extract as a neuroprotective against gamma irradiation. Cytotechnology, 65, 145-156.

Hu, J., Ferreira, A. and Van Eldik, L.J. (1997) S100 beta induces neuronal cell death through nitric oxide release from astrocytes. J. Neurochem. 69, 2294-2301.

Hua, K., Schindler, M.K., McQuail, J.A., Forbes, M.E. and Riddle, D.R. (2012) Regionally distinct responses of microglia and glial progenitor cells to whole brain irradiation in adult and aging rats. PLoS One, 7(12), e52728.

Huang, T-T., Zou, Y. and Corniola, R. (2012) Oxidative stress and adult neurogenesis - effects of radiation and superoxide dismutase deficiency. Semin Cell Dev. Biol. 23, 738-744.

Huo, K., Sun, Y., Li, H., Du, X., Wang, X., Karlsson, N., Zhu, C. and Blomgren, K. (2012) Lithium reduced neural progenitor apoptosis in the hippocampus and ameliorated functional deficits after irradiation to the immature mouse brain. Mol. Cell Neurosci. 51, 32-42.

Ingebrigtsen, T., Romner, B., Kongstad, P. and Langbakk, B. (1995) Increased serum concentrations of protein S-100 after minor head injury: A biochemical serum marker with prognostic value? J. Neurol. Neurosurg. Psychiatry, 59, 103-104.

Jiang, T., Zhang, Y.D., Chen, Q., Gao, Q., Zhu, X.C., Zhou, J.S., Shi, J.Q., Lu, H., Tan, L. and Yu, J.T.
(2016) TREM2 modifies microglial phenotype and provides neuroprotection in P301S tau transgenic mice. Neuropharmacology, 105, 196-206.

Kaca-Orynska, M., Tomasiuk, R. and Friedman, A. (2010) Neuron-specific enolase and S100B protein as predictors of outcome in ischaemic stroke. Neurol. Neurochir. Pol. 44(5), 459-463.

Kadifkova Panovska, T., Kulevanova, S. and Stefova, M. (2005) In vitro antioxidant activity of some Teucrium species (Lamiaceae). Acta Pharm. 55(2), 207-214.

Kalantari, H., Forouzandeh, H., Azemi, M.E., Rashidi, I., Goudarzi, M. (2013) Study of the protective effect of Teucrium polium L. extract on acetaminopheninduced hepatotoxicity in mice. Iran J. Pharm. Res. 12(1), 123-129.

Khleifat, K., Shakhanbeh, J. and Tarawneh, K. (2002) The chronic effects of Teucrium polium on some blood parameters and histopathology of liver and kidney in the rat. Turk. J. Biol. 26, 65-71.

Koppal, T., Lam, A.G., Guo, L. and Van Eldik, L.J. (2001) S100B proteins that lack one or both cysteine residues can induce inflammatory responses in astrocytes and microglia. Neurochem. Int. 39, 401407.

Laack, N.N. and Brown, P.D. (2004) Cognitive sequelae of brain radiation in adults. Semin Oncol. 31, 702-713.

Lee, B., Cao, R., Choi, Y.S., Cho, H.Y., Rhee, A.D., Hah, C.K., Hoyt, K.R. and Obrietan, K. (2009) The CREB/CRE transcriptional pathway: Protection against oxidative stress-mediated neuronal cell death. J. Neurochem. 108, 1251-1265.

Levy Nogueira, M., Epelbaum, S., Steyaert, J.M., Dubois, B. and Schwartz, L. (2016) Mechanical stress models of Alzheimer's disease pathology. Alzheimers Dement. 12(3), 324-333.

Li, P., Matsunaga, K., Yamakuni, T. and Ohizumi, Y. (2003) Nardosinone, the first enhancer of neurite outgrowth-promoting activity of staurosporine and dibutyryl cyclic AMP in PC12D cells. Brain Res. Dev. Brain Res. 145(2), 177-183.

Lipsky, R.H. and Marini, A.M. (2007) Brain-derived neurotrophic factor in neuronal survival and 
behavior-related plasticity. Ann. N Y Acad. Sci. 1122, 130-143.

Ljubuncic, P., Dakwar, S., Portnaya, I., Cogan, U., Azaizeh, H. and Bomzon, A. (2006) Aqueous extracts of Teucrium polium possess remarkable antioxidant activity in vitro. Evid Based Complement Alternat Med. 3(3), 329-338.

Lu, K., Zhang, C., Wu, W., Zhou, M., Tang, Y. and Peng, Y. (2015) Rhubarb extract has a protective role against radiation-induced brain injury and neuronal cell apoptosis. Mol. Med. Rep. 12, 2689-2694.

Machold, R. and Fishell, G. (2002) Hedgehog patterns midbrain ARChitecture. Trends Neuorosci. 25(1), 10-11.

Mao, X.W., Crapo, J.D. and Gridley, D.S. (2012) Mitochondrial oxidative stress-induced apoptosis and radioprotection in proton-irradiated rat retina. Radiat Res. 178, 118-125.

Marples, B., Wouters, B.G. and Joiner, M.C. (2003) An association between the radiation-induced arrest of G2-phase cells and low-dose hyper-radiosensitivity: A plausible underlying mechanism? Radiat. Res. 160(1), 38-45.

Mattson, M.P., Lovell, M.A., Furukawa, K. and Markesbery, W.R. (1995) Neurotrophic factors attenuate glutamate-induced accumulation of peroxides, elevation of intracellular $\mathrm{Ca}^{2+}$ concentration, and neurotoxicity and increase antioxidant enzyme activities in hippocampal neurons. J. Neurochem. 65(4), 1740-1751.

Mehrabani, D., Rezaee, A., Azarpira, N., Fattahi, M.R., Amini, M., Tanideh, N., Panjehshahin, M.R. and Saberi-Firouzi, M. (2009) The healing effects of Teucrium polium in the repair of indomethacininduced gastric ulcer in rats. Saudi Med. J. 30(4), 494-499.

Mercier, E., Boutin, A., Lauzier, F., Fergusson, D.A., Simard, J.F., Zarychanski, R., Moore, L., McIntyre, L.A., Archambault, P., Lamontagne, F., Legare, F., Randell, E., Nadeau, L., Rousseau, F. and Turgeon, AF. (2013) Predictive value of S-100 $\beta$ protein for prognosis in patients with moderate and severe traumatic brain injury: Systematic review and metaanalysis. BMJ. 346, f1757.

Miller, N.J., Rice-Evans, C., Davies, M.J., Gopinathan,
V. and Milner, A. (1993) A novel method for measuring antioxidant capacity and its application for monitoring the antioxidant status in premature neonates. Clin. Sci. 84, 407-412.

Minami, M. and Yoshikawa, H.A.(1979) Simplified assay method of superoxide dismutase activity for clinical use. Clin. Chim .Acta, 92, 337-342.

Moore, B.W. (1965) A soluble protein characteristic of the nervous system. Biochem. Biophys. Res. Commun. 19(6), 739-744.

Moosmann, B. and Behl, C. (2002) Antioxidants as treatment for neurodegenerative disorders. Expert. Opin. Investig. Drugs, 11(10), 1407-1435.

Mousavi, S.E., Shahriari, A., Ahangarpour, A., Vatanpour, H. and Jolodar, A. (2012) Effects of Teucrium polium ethyl acetate extract on serum, liver and muscle triglyceride content of sucroseinduced insulin resistance in rat. Iran. J. Pharm. Res. 11(1), 347-355.

Mousavi, S.M., Niazmand, S., Hosseini, M., Hassanzadeh, Z., Sadeghnia, H.R., Vafaee, F. and Keshavarzi, Z. (2015) Beneficial effects of Teucrium polium and metformin on diabetes- induced memory impairments and brain tissue oxidative damage in rats. Int. J. Alzheimers Dis. 2015(5), 493729.

Niazmand, S., Esparham, M., Hassannia, T. and Derakhshan, M. (2011) Cardiovascular effects of Teucrium polium L. extract in rabbit. Pharmacogn. Mag. 7(27), 260-264.

Oh, S.B., Park, H.R., Jang, Y.J., Choi, S.Y., Son, T.G. and Lee, J. (2013) Baicalein attenuates impaired hippocampal neurogenesis and the neurocognitive deficits induced by gamma-ray radiation. Brit. J. Pharmacol. 168, 421-431.

Ola, M.S., Aleisa, A.M., Al-Rejaie, S.S., Abuohashish, H.M., Parmar, M.Y., Alhomida, A.S. and Ahmed, M.M. (2014) Flavonoid, morin inhibits oxidative stress, inflammation and enhances neurotrophic support in the brain of streptozotocin-induced diabetic rats. Neurol. Sci. 35(7), 1003-1008.

Orhan, I. and Aslan, M. (2009) Appraisal of scopolamineinduced antiamnesic effect in mice and in vitro antiacetylcholinesterase and antioxidant activities of some traditionally used Lamiaceae plants. $J$. Ethnopharmacol. 122(2), 327-332. 
Otto, M., Bahn, E., Wiltfang, J., Boekhoff, I. and Beuche, W. (1998) Decrease of S100 beta protein in serum of patients with amyotrophic lateral sclerosis. Neurosci. Lett. 240(3), 171-173.

Panovska, T.K., Kulevanova, S., Gjorgoski, I., Bogdanova, M. and Petrushevska, G. (2007) Hepatoprotective effect of the ethyl acetate extract of Teucrium polium L. against carbontetrachlorideinduced hepatic injury in rats. Acta Pharm. 57(2), 241-248.

Parihar, V.K. and Limoli, C.L. (2013) Cranial irradiation compromises neuronal architecture in the hippocampus. Proc. Natl. Acad Sci. USA, 110, 12822-12827.

Patel, S.Sh. (2016) Ph.D. Thesis, Jaypee University of Information Technology, March, Chapter 2 review of literature.

Plog, B.A., Dashnaw, M.L., Hitomi, E., Peng, W., Liao, Y., Lou, N., Deane, R. and Nedergaard, M. (2015) Biomarkers of traumatic injury are transported from brain to blood via the glymphatic system. J Neurosci. 35, 518-526.

Proestos, C., Sereli, D. and Komaitis, M. (2006) Determination of phenolic compounds in aromatic plants by RP-HPLC and GCMS. Food Chem. 95(1), 44-52.

Qabaha, K.I. (2013) Antimicrobial and free radical scavenging activities of five Palestinian medicinal plants. Afr. J. Tradit. Complement Altern. Med. 10(4), 101-108.

Raabe, A., Grolms, C., Keller, M., Döhnert, J., Sorge, O. and Seifert, V. (1998) Correlation of computed tomography findings and serum brain damage markers following severe head injury. Acta Neurochir (Wien), 140(8), 787-791.

Rafieian-Kopaei, M. and Nasri, H. (2013) Comment on preventive effect of Teucrium polium on learning and memory deficits in diabetic rats. Med. Sci. Monit. Basic Res. 19, 208-209.

Rainey, T., Lesko, M., Sacho, R., Lecky, F. and Childs, C. (2009) Predicting outcome after severe traumatic brain injury using the serum S100B biomarker: Results using a single (24h) time-point. Resuscitation, 80(3), 341-345.
Rasekh, H.R. and Khoshnood-Mansourkhani, M.J., Kamalinejad, M. (2001) Hypolipidemic effects of Teucrium polium in rats. Fitoterapia, 72(8), 937939.

Rasekh, H.R., Yazdanpanah, H., Hosseinzadeh, L., Bazmohammadi, N. and Kamalinejad, M. (2005) Acute and subchronic toxicity of Teucrium polium total extract in rats. Iran. J. Pharm. Res. 4, 245-249.

Régis, J., Bartolomei, F., Metellus, P., Rey, M., Genton, P., Dravet, C., Bureau, M., Semah, F., Gastaut, J.L., Peragut, J.C. and Chauvel, P. (1999) Radiosurgery for trigeminal neuralgia and epilepsy. Neurosurg Clin. N. Am. 10(2), 359-377.

Rola, R., Zou, Y., Huang, T.T., Fishman, K., Baure, J., Rosi, S., Milliken, H., Limoli, C.L. and Fike, J.R. (2007) Lack of extracellular superoxide dismutase (EC-SOD) in the microenvironment impacts radiation-induced changes in neurogenesis. Free Radic Biol. Med. 42(8), 1133-1145.

Rola, R., Fishman, K., Baure, J., Rosi, S., Lamborn, K.R., Obenaus, A., Nelson, G.A. and Fike, J.R. (2008) Hippocampal neurogenesis and neuroinflammation after cranial irradiation with (56)Fe particles. Radiat. Res. 169(6), 626-632.

Romner, B., Ingebrigtsen, T., Kongstad, P. and Borgesen, S.E. (2000) Traumatic brain damage: Serum S-100 protein measurements related to neuroradiological findings. J. Neurotrauma, 17, 641-647.

Rothermundt, M., Peters, M., Prehn, J.H. and Arolt, V. (2003) S100B in brain damage and neurodegeneration. Microsc. Res Tech. 60, 614-632.

Sharma, N. and Nehru, B. (2016) Apocyanin, a microglial NADPH oxidase inhibitor prevents dopaminergic neuronal degeneration in lipopolysaccharideinduced Parkinson's disease model. Mol. Neurobiol. 53(5), 3326-3337.

Sindic, C.J., Chalon, M.P., Cambiaso, C.L., Laterre, E.C. and Masson, P.L. (1982) Assessment of damage to the central nervous system by determination of S-100 protein in the cerebrospinal fluid. J. Neurol. Neurosurg. Psychiatry, 45, 1130-1135.

Suboh, S.M., Bilto, Y.Y. and Aburjai, T.A. (2004) Protective effects of selected medicinal plants against protein degradation, lipid peroxidation and deformability loss of oxidatively stressed human 
erythrocytes. Phytother. Res. 18(4), 280-284.

Suleiman, M-S., Abdul-Ghani, A-S., Al-Khalil, S. and Amin, R. (1988) Effect of Teucrium polium boiled leaf extract on intestinal motility and blood pressure. J. Ethnopharmacol. 22(1), 111-116.

Tariq, M., Ageel, A.M., Al-Yahya, M.A., Mossa, J.S. and Al-Said, MS.. (1989) Anti-inflammatory activity of Teucrium polium. Int. J. Tissue React. 11(4), 185188.

Thelin, E.P., Johannesson, L., Nelson, D. and Bellander, B.M. (2013) S100B is an important outcome predictor in traumatic brain injury. J. Neurotrauma, 30(7), 519-528.

Todorovic, A., Pejic, S., Stojiljkovic, V., Gavrilovic, L., Popovic, N., Pavlovic, I., Saicic, Z.S. and Pajovic, S.B. (2015) Antioxidative enzymes in irradiated rat brain-indicators of different regional radiosensitivity. Childs Nerv. Syst. 31, 2249-2256.

Tsai, C.Y., Chan, J.Y., Hsu, K.S., Chang, A.Y. and Chan, S.H. (2012) Brain-derived neurotrophic factor ameliorates brain stem cardiovascular dysregulation during experimental temporal lobe status epilepticus. PLoS One, 7(3), e33527.

Unden, J. and Romner, B. (2010) Can low serum levels of S100B predict normal CT findings after minor head injury in adults?: an evidence-based review and meta-analysis. J. Head Trauma Rehabil. 25, 228240.

Unden, J., Bellner, J., Astrand, R. and Romner, B. (2005) Serum S100B levels in patients with epidural haematomas. Br. J. Neurosurg. 19, 43-45.

Undén, L., Calcagnile, O., Undén, J., Reinstrup, P. and Bazarian, J. (2015) Validation of the Scandinavian guidelines for initial management of minimal, mild and moderate traumatic brain injury in adults. $B M C$ Med. 13, 292.

Van Eldik, L.J. and Wainwright, M.S. (2003) The Janus face of glial-derived S100B: Beneficial and detrimental functions in the brain. Restor. Neurol. Neurosci. 21(3-4), 97-108.

Wang, J., Song, N., Jiang, H., Wang, J. and Xie, J. (2013) Pro-inflammatory cytokines modulate iron regulatory protein 1 expression and iron transportation through reactive oxygen/nitrogen species production in ventral mesencephalic neurons. Biochim. Biophys. Acta, 1832(5), 618-625.

Weglewski, A., Ryglewicz, D., Mular, A. and Juryńczyk, J. (2005) Changes of protein S100B serum concentration during ischemic and hemorrhagic stroke in relation to the volume of stroke lesion. Neurol. Neurochir. Pol. 39(4), 310-317.

Xin, N., Li, Y.J., Li, X., Wang, X., Li, Y., Zhang, X., Dai, R.J., Meng, W.W., Wang, H.L., Ma, H., Schläppi, M. and Deng, Y.L. (2012) Dragon's blood may have radioprotective effects in radiation-induced rat brain injury. Radiat. Res. 178(1), 75-85.

Ye, J., Jiang, Z., Chen, X., Liu, M., Li, J. and Liu, N. (2016) Electron transport chain inhibitors induce microglia activation through enhancing mitochondrial reactive oxygen species production. Exp. Cell Res. 340, 315-326.

Yoshioka, T., Kawada, K., Shimada, T. and Mori, M. (1979) Lipid peroxidation in maternal and cord blood and protective mechanism against activated oxygen toxicity in the blood. Am. J. Obstet. Gynecol. 135, 372-376.

Yuste, J.E., Tarragon, E., Campuzano, C.M., and RosBernal, F. (2015) Implications of glial nitric oxide in neurodegenerative diseases. Front Cell Neurosci. 9, 322.

Zabihi, N.A., Mousavi, S.M., Mahmoudabady, M., Soukhtanloo, M., Sohrabi, F. and Niazmand, S. (2018) Teucrium polium L. improves bloodglucose and lipids and ameliorates oxidative stressin heart and aorta of diabetic rats. Int. J. Prev. Med. 9, 110.

Zhang, L., Li, K., Sun, R., Zhang, Y., Ji, J., Huang, P., Yang, H. and Tian, Y. (2014) Minocycline ameliorates cognitive impairment induced by wholebrain irradiation: An animal study. Radiat. Oncol. 9, 281.

Zhang, Y., Cheng, Z., Wang, C., Ma, H., Meng, W. and Zhao, Q. (2016) Neuroprotective effects of kukoamine A against radiation-induced rat brain injury through inhibition of oxidative stress and neuronal apoptosis. Neurochem. Res. 41(10), 25492558 .

(Received 21/2/2019; accepted 26/3 /2019) 


\section{الدور المحسن لمستخلص نبات الجعدة على تسمم الإشعاع الجامي في مخ الجرذان البيضاء}

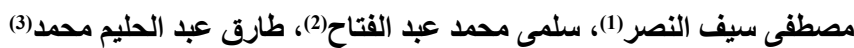

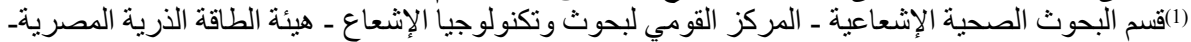

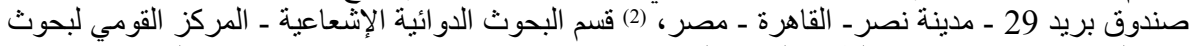

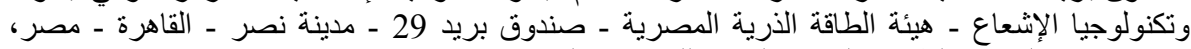
(3)قتم كيمياء النباتات الطبية ـ المركز القومى للبحوثة ـ الجيزة ـ ـ صندوق بريد 12622 ـ مصر.

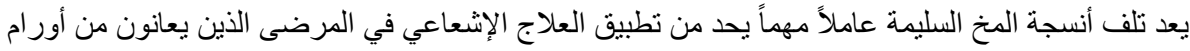

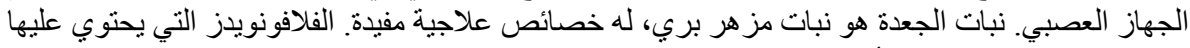

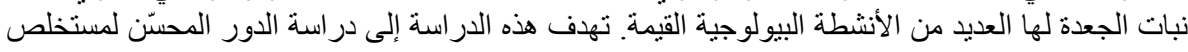

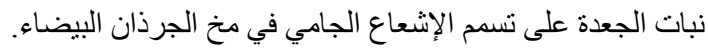

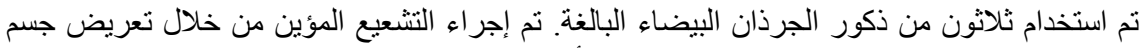

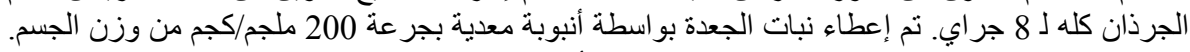

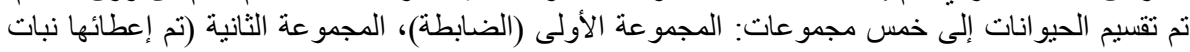

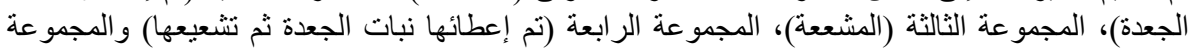

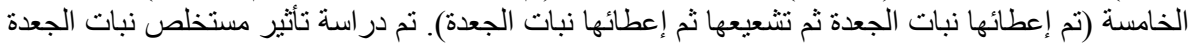

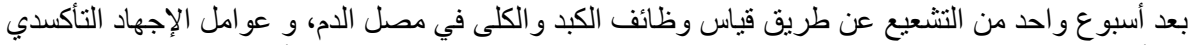

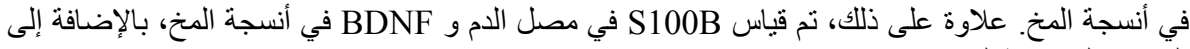
الفحص الهسنوباتولوجي.

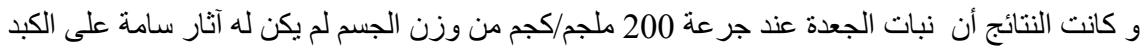

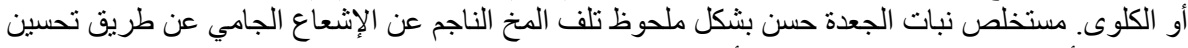

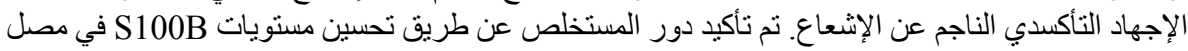

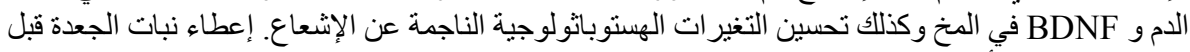
وبعد التشعيع كان أكثر فعالية من إعطائه فقط قبل التشعيع. كثفت هذه النتائج أن إعطاء مستخلص نبات الجعدة قد يحسن ضرر المخ الناجم عن الإشعاع الجامي عن

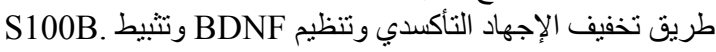

